\title{
MERDEKA BELAJAR DALAM PERSPEKTIF HUKUM INDONESIA
}

\author{
Dwi Nur Fauziah Ahmad1, Ahmad Arif fadilah², Dwi Citra Ningtyas ${ }^{3}$, Sarah Nurmila Putri ${ }^{4}$ \\ 1234Universitas Muhammadiyah Tangerang
}

Jalan Perintis Kemerdekaan I Babakan No.33, RT.007/RW.003, Cikokol, Kec. Tangerang, Kota Tangerang, Banten 15118

*Correspondence email: Sarahputri.sp0204@gmail.com

\begin{abstract}
ABSTRAK Education is a tool to achieve happiness and prosperity for all mankind, quality education will reflect a progressive society that is peaceful and leads to constructive traits. Education is also a driving wheel so that the culture and habits of each era change according to the changes that are obtained from education itself. So when you want to achieve a better life, of course, education is the answer, because education brings creative, innovative things to live in every era. Freedom to learn is a new policy program of the Ministry of Education and Culture of the Republic of Indonesia. The Minister of Education and Culture has issued Circular (SE) Number 1 of 2020 concerning the Freedom of Learning Policy in determining Student Graduation and Admission of New Students for the 2020/2021 Academic Year which is addressed to Governors and Regents / Mayors throughout Indonesia. Merdeka Belajar is a new concept in the National Education System. The concept is that students and students are given the freedom to choose their learning activities. It takes the readiness of teachers and lecturers in an effort to respond to the policy.
\end{abstract}

KEYWORDS: Education, Free Learning

\section{PENDAHULUAN}

Pendidikan merupakan tumpuan utama dalam membimbing serta mengarahkan generasi Bangsa Indonesia, karena didalamnya terdapat proses pembelajaran, bimbingan serta tujuan dilaksanakannya proses pembelajaran.(Farikhah, 2015; Junaid, 2016) Pelaksanaan proses belajar mengajar harus bertumpu pada siswa atau pelajar karena harapannya bukan guru yang mempunyai karakter dan kreatifitas melainkan siswanya itu sendiri. Ketika harapan tidak sesuai dengan kenyataan maka disitulah kegagalan ditanggung Bersama.(Suprayitno \& Wahyudi, 2020) Pada prinsipnya Pendidikan dilaksanakan untuk mengangkat harkat dan martabat manusia sebagai warga negara Indonesia yang berhak mendapatkan perhatian pemerintah, perlindungan dan Pendidikan.(Hakim, 2016; Sirait, 2017) Mencerdaskan kehidupan bangsa adalah tujuan utama Pendidikan.(Ali, 2009) Tujuan ini disampaikan Pasal 31 Ayat 3 UUD 1945. Pada pasal tersebut dinyatakan pemerintah mengusahakan dan menyelenggarakan satu system Pendidikan Nasional, yang meningkatkan keimanan dan ketakwaan serta ahlak mulia dalam 
rangka mencerdaskan kehidupan bangsa. Untuk mewujudkan tujuan ini, pemerintah mempercayakan kepada guru di sekolah.(Sherly et al., 2020)

Dalam pandangan agama khususnya agama Islam, belajar menjadi hal pertama yang diperintahkan Allah SWT.(Nata, 2016; Sulaiman et al., 2018) dalam Qur'an surat Al'Alaq Ayat 1-5 adalah dalilnya sebagai ayat yang pertama kali turun. Allah SWT berfirman : "(1) Bacalah dengan (menyebut) nama Tuhanmu yang Menciptakan, (2) Dia telah menciptakan manusia dari segumpal darah, (3) Bacalah, dan Tuhanmulah yang Maha pemurah, (4) yang mengajar (manusia) dengan perantaran kalam, (5) Dia mengajar kepada manusia apa yang tidak diketahuinya." Melalui QS Al'Alaq 1-5 tersebut Allah SWT meminta umat Nabi Muhammad untuk belajar -menuntut ilmu-. Allah SWT meminta manusia untuk membaca dan menjalankan kegiatan belajar mengajar. Melepaskan diri dari buta aksara. Menjadi orang-orang berilmu. Memiliki bekal ilmu dan iman dalam menjaga alam dan kehidupan. Mewujudkan Islam yang rahmatan lil'alamin. Menjadi hamba Allah SWT dan membuktikan diri sebagai umat terbaik (QS. Ali Imran: 110).(Hayati, 2018; Rohidayati, 2015)

Merdeka Belajar adalah program kebijakan baru Kementrian Pendidikan dan Kebudayaan Republik Indonesia (Kemendikbud RI). (Arifin \& Muslim, 2020; Mustaghfiroh, 2020) Mendikbud telah menerbitkan Surat Edaran (SE) Nomor 1 Tahun 2020 tentang Kebijakan Merdeka Belajar dalam Penentuan Kelulusan Peserta Didik dan Penerimaan Peserta Didik Baru Tahun Ajaran 2020/2021yang ditujukan kepada Gubernur dan Bupati/Walikota Seluruh Indonesia.(Chrismastianto, 2021) Merdeka belajar ini dicanangkan oleh Mentri Nadiem Anwar Makarim dengan harapan program tersebut dibentuk agar menciptakan suasana belajar yang bahagia, tidak bosan dan agar belajar itu dijadikan hobby oleh peserta didik dan menjadi arah pembelajaran yang focus pada eningkatkan kualitas sumber daya manusia.(Muhsin, 2021) Menurut Nadiem esensi kemerdekaan berpikir itu harus didahului oleh para guru sebelum mereka mengajarkan kepada siswa - siswinya. Program merdeka belajar ini dilahirkan dari banyaknya keluhan di sistem Pendidikan. Salah satu keluhan soal banyaknya peserta didik yang dipatok oleh nilai - nilai tertentu.(Wijayanto, 2021)

Perspektif merdeka belajar banyak menuai pro kontra didalam sistem Pendidikan, oleh karena itu sebelum adanya program ini pemerintah telah mengkaji beberapa poin yang ada di program merdeka belajar dengan didasari oleh hukum - hukum yang ada di Indonesia supaya dapat dipahami secara utuh tentang konsep Merdeka Belajar.(Wijayanto, 2021)

Berdasarkan latar belakang ini penulis akan mengkaji dan juga mengaanalisa terkait merdeka belajar secara landasan hukum yang dicanangkan konsep merdeka belajar oleh 
Kemendikbud Republik Indonesia, factor apa saja yang menjadi penghambat dalam program merdeka belajar dan keuntungan baik kerugian yang dirasakan oleh guru Orang Tua dan Peserta Didik dengan adanya konsep Merdeka Belajar tersebut.

\section{METODE PENELITIAN}

Metode yang digunakan dalam pembuatan jurnal ini adalah studi kepustakaan yang didukung dengan sumber referensi yang relevan sesuai dengan tema yang diangkat tentang merdeka belajar, mulai dari jurnal dan juga artikel yang masih berkaitan.(Gunawan, 2013)

\section{HASIL DAN ANALISA}

\section{Landasan Hukum Program Merdeka Belajar}

Program Merdeka belajar menurut Mendikbud akan menjadi arah pembelajaran kedepan yang focus pada meningkatkan kualitas sumber daya manusia, sebagaimana dasar hukum yang menyertai upaya meningkatkan kualitas SDM di Indonesia dilandasi dengan tanggung jawab untuk menjalankan amanat :(Tohir, 2020)

a. Pembukaan UUD 1945 alinea IV dalam rangka mencerdaskan kehidupan bangsa;

b. Pasal 31 ayat (3) yang menyatakan bahwa pemerintah mengusahakan dan menyelenggarakan suatu sistem Pendidikan nasional dalam rangka mencerdaskan kehidupan bangsa;

c. UU Sisdiknas Tahun 2003 menimbang bahwa sistem Pendidikan nasional harus mampu menjamin pemerataan kesempatan Pendidikan, peningkatan mutu, serta relevansi dan efisiensi manajemen Pendidikan untuk menghadapi tantangan sesuai dengan tuntutan perubahan kehidupan local, nasional, dan global sehingga perlu dilakukan pembaharuan Pendidikan secara terencana, terarah, dan berkesinambungan;

d. UU Sisdiknas Tahun 2003 Pasal 3 menyebutkan bahwa Pendidikan nasional berfungsi mengembangkan kemampuan dan membentuk watak serta peradapan bangsa yang bermartabat dalam rangka mencerdakan kehidupan bangsa, bertujuan untuk berkembangnya potensi peserta didik agar menjadi manusia yang beriman dan bertakwa kepada Tuhan Yang Maha Esa, berakhlak mulia, sehat, berilmu, cakap, kreatif mandiri, dan menjadi warga negara yang demokratis serta bertanggungjawab; dan

e. Nawacita kelima untuk meningkatkan kualitas hidup manusia Indonesia. Program pendidikan "Merdeka Belajar" meliputi empat pokok kebijakan, antara lain: 1) Ujian Sekolah Berstandar Nasional (USBN); 2) Ujian Nasional 
(UN); 3) Rencana Pelaksanaan Pembelajaan (RPP), dan 4) Peraturan Penerimaan Peserta Didik Baru (PPDB) zonasi. Bila dicermati dari isi pokok kebijakan merdeka belajar jelas lebih difokuskan pada jenjang pendidikan dasar dan menengah, meskipun pada perkembangan selanjutnya berdimensi juga ke jenjang pendidikan tinggi (Dikti) melalui program "Kampus Merdeka". Pastinya program "Merdeka Belajar" bukanlah sebuah kebijakan yang secara tiba-tiba muncul, melainkan melalui serangkaian proses yang panjang dan matang, setelah beberapa waktu lalu pasca dilantik menjadi Mendikbud banyak melakukan kajian komprehensif dengan mengundang dan mendatangi para pakar pendidikan, pengawas, kepala sekolah, guru-guru, organisasi profesi guru dan lain sebagainya, untuk mendengar berbagai masukan terkait permasalahan praktik pendidikan. Lebih jelasnya lagi keempat prinsip merdeka belajar tersebut diuraian sebagai berikut.

1) Ujian Sekolah Berstandar Nasional (UASBN)

Berdasarkan Permendikbud Nomor 43 Tahun 2019, tentang Penyelenggaraan Ujian yang Diselengarakan Satuan Pendidikan dan Ujian Nasional, khususnya pada Pasal 2, ayat 1; menyatakan bahwa ujian yang diselenggarakan oleh satuan pendidikan merupakan penilaian hasil belajar oleh satuan pendidikan yang bertujuan untuk menilai pencapaian standar kompetensi lulusan untuk semua mata pelajaran.(Herkusumo, 2011) Selanjutnya dijelaskan pada Pasal 5, ayat 1, bahwa; bentuk ujian yang diselenggarakan oleh Satuan Pendidikan berupa portofolio, penugasan, tes tertulis, atau bentuk kegiatan lain yang ditetapkan Satuan Pendidikan sesuai dengan kompetensi yang diukur berdasarkan Standar Nasional Pendidikan. Ditambahkan pula pada penjelasan Pasal 6, ayat 2, bahwa; untuk kelulusan peserta didik ditetapkan oleh satuan pendidikan/program pendidikan yang bersangkungan. Dengan demikian jika melihat isi Permendikbud tersebut menunjukkan, bahwa Guru dan sekolah lebih merdeka untuk menilai hasil belajar siswa.(Suwandi, 2013)

2) Ujian Nasional (UN)

Ujian Nasional (UN) adalah kegiatan pengukuran capaian kompetensi lulusan pada mata pelajaran tertentu secara nasional dengan mengacu pada standar kompetensi lulusan.(Mardapi \& Kartowagiran, 2009) Merupakan penilaian hasil belajar oleh pemerintah pusat yang bertujuan untuk menilai pencapaian kompetensi lulusan secara nasional pada mata 
pelajaran tertentu (Permendikbud No. 43 Tahun 2019). Terkait untuk pelaksanaan UN tahun 2020, sebagaimana disampaikan Mendikbud merupakan kegiatan UN yang terakhir kalinya, selanjutnya ditahun 2021 mendatang UN akan digantikan dengan istilah lain yaitu Asesmen Kompetensi Minimun dan Survey Karakter. Asesmen dimaksudkan untuk mengukur kemampuan peserta didik untuk bernalar menggunakan bahasa dan literasi, kemampuan bernalar menggunakan matematika atau numerasi, dan penguatan pendidikan karakter. Adapun untuk teknis pelaksanaan ujian tersebut akan dilakukan ditengah jenjang sekolah. Misalnya di kelas 4, 8, 11, dengan maksud dapat mendorong guru dan sekolah untuk memetakan kondisi pembelajaran, serta mengevaluasi sehingga dapat memperbiki mutu pembelajaran. Dengan kata lain, agar bisa diperbaiki kalau ada hal yang belum tercapai. Sebagai catatan hasil ujian ini tidak digunakan sebagai tolok ukur seleksi siswa kejenjang berikutnya. Adapun untuk standarisasi ujian, arah kebijakan ini telah mengacu pada level internasional, mengikuti tolok ukur penilain yang termuat dalam Programme for International Student Assessment (PISA) dan Trends in International Mathematics and Science Study (TIMSS), tetapi penuh dengan kearifan lokal (Media Indonesia, 12/12/2019). Untuk kompetensi PISA lebih difokuskan pada penilaian kemampuan membaca, matematika, dan sains, yang diberlakukan pada negara-negara yang tergabung dalam Organization for Economic Cooperation and Development (OECD), sedangkan untuk kompetensi TIMSS lebih menekankan pada penilaian kemampuan matematika, dan sains, sebagai indikator kualitas pendidikan, yang tergabung dalam wadah International Association for the Evaluation of Educational Achievement, berpusat di Boston, Amerika Serikat.

Terkait Asesmen Kompetensi Minimum dan Survei Karakter, dimaksudkan supaya setiap sekolah bisa menentukan model pembelajaran yang lebih cocok untuk murid-murid, daerah, dan kebutuhan pembelajaran mereka, serta Asesmen Kompetensi Minimum tidak sekaku UN, seperti yang disampaikan Dirjen GTK Supriano Selanjutnya untuk aspek kognitif Asessmen Kompetensi Minimum, menurut Mendikbud materinya dibagi dalam dua bagian: (1) Literasi; bukan hanya kemampuan untuk membaca, tapi juga kemampuan menganalisa suatu bacaan, kemampuan memahami 
konsep di balik tulisan tersebut; (2) Numerasi; berupa kemampuan menganalisa, menggunakan angka-angka. Jadi ini bukan berdasarkan mata pelajaran lagi, bukan penguasaan konten, atau materi. Namun ini didasarkan kepada kompetensi dasar yang dibutuhkan murid-murid untuk bisa belajar, apapun mata pelajarannya.(Maisaroh \& Falah, 2021)

\section{3) Rencana Pelaksanaan Pembelajaran (RPP)}

Dalam hal RPP, berdasarkan Surat Edaran Mendikbud Nomor 14 Tahun 2019, tentang Penyederhanaan RPP, isinya meliputi: (1) penyusunan RPP dilakukan dengan prinsip efisien, efektif, dan berorientasi pada siswa; (2) Dari 13 komponen RPP yang tertuang dalam Permendikbud Nomor 22 Tahun 2016, yang menjadi komponen inti adalah tujuan pembelajaran, langkah-langkah pembelajaran, dan penilaian pembelajaran (assesment) yang wajib dilaksanakan oleh guru, sedangkan sisanya hanya sebagai pelengkap; dan (3) Sekolah, Kelompok Guru Mata Pelajaran dalam sekolah, Kelompok Kerja Guru/Musyawarah Guru Mata Pelajaran (KKG/MGMP) dan individu guru secara bebas dapat memilih, membuat, menggunakan, dan mengembangkan format RPP secara mandiri untuk sebesar-besarnya keberhasilan belajar siswa. Adapun RPP yang telah dibuat dapat digunakan dan dapat disesuaikan dengan ketentuan sebagaaimana maksud pada angka 1, 2, dan 3. (Prastowo, 2017)

Bila dicermati dari keseluruhan isi surat edaran mendikbud tersebut, dapat dimaknai bahwa penyusunannya lebih disederhanakan dengan memangkas beberapa komponen. Guru diberikan keleluasaan dalam proses pembelajaran untuk memilih, membuat, menggunakan, dan mengembangkan format RPP, sebab gurulah yang mengetahui kebutuhan siswa didiknya dan kebutuhan khusus yang diperlukan oleh siswa di daerahnya, karena karakter dan kebutuhan siswa di masing-masing daerah bisa berbeda. Untuk penulisan RPP-nya supaya lebih efisiensi dan efektif, cukup dibuat ringkas bisa dalam satu halaman, sehingga guru tidak terbebani oleh masalah administrasi yang rijit. Diharapkan melalui kebebasan menyusun RPP kepada guru, siswa akan lebih banyak berinteraksi secara aktif, dinamis, dengan model pembelajaran yang tidak kaku.(Wikanengsih et al., 2015) 


\section{4) Peraturan Penerimaan Peserta Didik Baru (PPSDB)}

Untuk PPDB, berdasarkan Permendikbud baru Nomor 44 Tahun 2019 tentang PPDB 2020, sebagaimana dinyatakan pada Pasal 11, dalam persentase pembagiannya meliputi: (1) untuk jalur zonasi paling sedikit 50 persen; (2) jalur afirmasi paling sedikit 15 persen; (3) jalur perpindahan tugas orang tua/wali lima persen; dan (4) jalur prestasi (sisa kuota dari pelaksanaan jalur zonasi, afirmasi dan perpindahan orang tua /wali (0-30 persen).(Lestari \& Rosdiana, 2018) Jelas ini berbeda dengan kebijakan PPDB pada tahun-tahun sebelumnya, setidaknya terdapat dua hal penting: (1) kuota penerimaan siswa baru lewat jalur berprestasi, semula 15 persen, sekarang menjadi 30 persen; dan (2) adanya satu penambahan baru jalur PPDB, yaitu melalui jalur afirmasi, yang ditujukan terutama bagi mereka yang memegang Kartu Indonesia Pintar (KIP). Dengan demikian untuk PPDB 2020 masih tetap menggunakan sistem zonasi, akan tetapi dalam pelaksanaannya lebih bersifat fleksibel, dengan maksud agar dapat mengakomodir ketimpangan akses dan kualitas di berbagai daerah. (Purwanti, 2019) Terpenting dalam prorporsi finalisasinya, daerah berwenang untuk menentukan dan menetapkan wilayah zonasinya. Secara umum sistem zonasi dalam PPDB itu sudah baik, karena dapat mendorong hilangnya diskriminasi bagi anggota masyarakat untuk bersekolah di sekolah-sekolah terbaik.(Purwanti et al., 2019)

\section{Faktor yang menghambat dicanangkan konsep Merdeka Belajar, yaitu:}

\section{a. Ketika Tidak Terbangun Sense Of Agency}

Agency biasanya dikaitkan dengan pemikiran tentang ownership siswa dalam proses belajar dalam artian siswa mampu membuat keputusan sendiri dan berkomitmen dengan keputusannya itu, mampu merumuskan sendiri tujuan belajarnya dan bertanggung-jawab dengan apa pun hasilnya, mampu membuat arah kegiatan belajarnya sendiri serta siap dengan konsekuensinya--serba superlatif, sebagaimana istilah student agency: agent for the change of one's own self. Namun jika situasinya seperti ini tentu tidak diperlukan kehadiran guru untuk membimbing siswa. Normalnya kemampuan superlatif agency hanya bisa berjalan bila seseorang telah memiliki kapasitas yang cukup untuk membuat pilihan-pilihan dan berkomitmen dengan pilihan-pilihan tersebut (the capacity without which agency cannot be assumed).(Wijayanto, 2021) 
Yang dimaksud di sini adalah sense of agency (tekanan pada SENSE) yakni bahwa siswa memiliki kesadaran bahwa dirinya sejatinya adalah subyek (Jawa: diwongke) dalam keseluruhan proses: kehadirannya diberi tempat, pikirannya dipandang positif, dan partisipasinya dihargai. Siswa yang sebelumnya memiliki kesan bahwa dirinya obyek dan pasif (diposisikan: diajari, ditugasi, dievaluasi) menjadi berpikir subyek dengan atribut-atribut positif (berposisi: mampu belajar, mengemban tugas, menilai diri sendiri).

Tugas Merdeka Belajar adalah memastikan untuk menghilangkan kendala yang menghambat proses ini. Kendala yang menghambat ini bisa dikatakan berhasil dilenyapkan bila sense of agency ini berhasil dimiliki dengan sadar bukan hanya oleh satu atau dua orang siswa secara individu semata, melainkan menjadi features yang shared bersama seluruh kelas.

Strategi untuk membangun sense of agency yang mudah dilakukan adalah mendesain pembelajaran yang memotivasi kemampuan berpikir divergen; atau lebih tepatnya metode berpikir convergent-divergent dan divergent-convergent secara taktis. Tantangannya tentu ada pada guru dalam mendesain skenario akses sedemikian rupa sehingga siswa mampu masuk ke dalam metode berpikir seperti yang dimaksud. Tantangan tersebut berupa konten dan pedagogis; konten berarti penguasaan dan pemahaman yang baik atas materi pembelajaran, dan pedagogis berarti pengelolaan dan eksekusi satuan prosedur untuk mengusung penguasaan konten pada siswa.

\section{b. Ketika Lingkungan Tidak Kondusif}

Lingkungan pendidikan bisa manifest by-chance, bisa by-design. By-chance artinya lingkungan sudah ada tanpa perlu dipersiapkan terlebih dahulu sebelumnya, tanpa harus menjawab pertanyaan what-why-how here/there. Bydesign artinya lingkungan dipersiapkan lebih dulu dengan matang sesuai kaidahkaidah didaktik-pedagogis. Lingkungan seperti ini dirancang dengan sadar, berbasis ilmu dan kearifan, untuk memenuhi semua keperluan agar proses pembelajaran berlangsung efektif.

Lingkungan kelas (sekolah, kampus) by-design memiliki dimensi struktur dan kultur. Disebut berdimensi struktur karena kelas adalah komponen organik institusi di atasnya dengan garis hierarki dan fungsi yang jelas. Konten materi dan segala sesuatu yang terkait dengan satuan operasional pembelajaran adalah fragmen (albeit focal) dari keseluruhan ekosistem yang besar. Disebut berdimensi kultur karena nilai dan norma yang melandasi praktek-praktek 
pembelajaran di kelas adalah hasil konvensi yang membentuk tradisi, dan akibat langsung dari sistem "kesadaran" yang dibangun oleh unit-unit pikiran dari waktu ke waktu. Dimensi kultur mewarnai sikap dan ideolektik baik dalam materi, media, prakondisi, maupun skenario pembelajaran.

Kedua dimensi lingkungan ini akan membentuk dan memberi warna proses dan hasil pembelajaran. Uniknya, guru berdiri di atas dua kaki: sebagai bagian dari struktur sekolah yang adalah perpanjangan tangan kekuasaan organisasi sekolah dan lembaga di atasnya; namun di sisi lain ia juga berposisi sebagai bagian dari dari siswa dalam konteks skenario pembelajaran (guru-proses-murid): guru mengajar dan murid belajar dalam kesatuan proses.

\section{c. Ketika Tidak Diperoleh Model}

Sebuah model merupakan gambaran tentang suatu entitas atau realitas yang dipandang paling representatif dari sehimpunan kasus-kasus yang ditentukan. Misalnya, sebuah model tentang teks deskriptif, lisan atau tulisan (untuk contoh kasus kita ambil yang tulisan). Dari tujuannya, teks jenis ini ingin menggambarkan suatu obyek secara detail sedemikian rupa sehingga pembaca dapat menangkap citra tentang obyek tersebut perinci sebagaimana digambarkan. Namun hal ini dilakukan dalam waktu dan tempat yang serba terbatas, katakanlah dalam 100-200 kata (tanpa modalitas visual atau apa pun yang lain, murni dalam dimensi kata) yang pembaca selesai menyimaknya dalam waktu kurang lebih 5 menit dengan hasil paripurna. Maksudnya, gambaran yang ada dalam pikiran pembaca sebisa mungkin persis menyerupai gambaran yang ada dalam pikiran penulis.

Dengan keterbatasan modalitas dan waktu maka diperlukan model yang tepat untuk keperluan ini. Berbeda bila situasinya here-now dan serba "mewah"; misalnya, barangnya bisa dihadirkan, siswa bisa berinteraksi dengan barang, terdapat perangkat audio-visual multiple dimensi, waktu luang yang banyak untuk mengeksplorasi, siswa telah sering melihat barang tersebut, dll. (biasanya sekolah-sekolah tertentu yang serba lengkap media centernya memiliki kemewahan ini dan sanggup menghadirkan obyek sehingga dimensi-dimensi yang diperlukan dapat diinderai secara rinci; tapi kebanyakan sekolah tidak demikian). Maka dapat dipastikan tanpa memperhatikan kaidah-kaidah model teks yang sesuai hampir pasti tujuan menggambarkan obyek tidak tercapai dengan baik. 
Teks deskriptif banyak digunakan oleh guru dan mahasiswa PPL (Praktek Pengalaman Lapangan) untuk mempraktekkan ilmu mengajar, sesuai dengan tuntutan konten materi. Penulis sering menjumpai, teks yang tampak sepele ini ternyata tidak semudah yang dibayangkan dalam kenyataan di lapangan, terlebih dalam konteks pedagogi formal. Dari pengamatan kesulitan bisa terletak pada empat tempat: 1) ketidak-siapan siswa untuk belajar jenis kemampuan ini dari segi entry level dan schemata; 2) penguasaan genre yang lemah pada sisi pengajar; 3) ketidak-sesuaian pemahaman model antara siswa dan pengajar; dan 4) pemilihan contoh teks yang tidak tepat (tidak memenuhi kaidah model teks deskriptif yang baik) untuk mengilustrasikan materi.

Kesulitan yang inheren dan khas untuk memahami sebuah model (misalnya deskripsi sebuah obyek) juga bisa terletak pada sub-sub deskripsi yang membentuk features tersendiri yang menjadikannya sub-model terpisah. Misalnya, gambaran kucing. Sebelum tiba pada penggambaran kucing tertentu biasanya deskripsi merujuk pada sub-sub model pembentuk entitas kucing pada umumnya yang serba khas (yang lebih bersifat report genre); misalnya, mata, telinga, kumis, bulu, ukuran, dll; kemudian model kucing yang bersifat umum.Sekedar berbagi, penulis sendiri pernah mengalami kesulitan memahami pengertian quantum leap karena deskripsi yang lemah. Yang muncul di pikiran ketika awal mula mendengar istilah tersebut adalah katak yang bisa melompat jauh sekali jejak (leap); atau panther yang berlari kencang dengan lompatanlompatan panjang dan cepat. Jadi yang muncul pertama dalam pikiran adalah "conceptual model of leap".

Kesulitan berikutnya adalah pengertian kuantum. Dalam bayangan penulis, di mana kuantumnya si katak ini? Yang sudah dipahami adalah bahwa kuantum artinya hitungan dalam satuan-satuan. Terkait quantum leap, yang sedang dipelajari adalah tentang atom; bayangan tentang atom adalah ledakan di Hiroshima dan Nagasaki. Adakah hubungan antara loncatan katak dengan ledakan atom seperti di Hiroshima? Bagi penulis yang lugu ini, perlu gambaran yang jelas dan gampang dimengerti tentang quantum ini, dan harus ketemu modelnya, baru kemudian mengerti apa itu quantum leap. Jadi diperlukan model utama (quantum leap model), sub-sub model (leap model dan quantum model, yang membangun model utama), dan model penyerta (atomic orbital, physics, yang berfungsi konteks). Kegagalan menghadirkan model-model yang sesuai 
agar memahami materi dengan konsep-konsep tertentu akan berkontribusi pada kemandekan siswa dalam proses berpikirnya.

Bila bangunan ilmu diandaikan bangunan rumah (gaya berpikir Bernsteinian), maka mencari ilmu adalah seperti membangun rumah. Alam pikir siswa melengkapi dirinya dengan konsep dasar tentang rumah dan konsep dasar ini menjadi model heuristik bagi dirinya ketika membangun rumah atau ketika mengembangkan rumahnya: bagaimana mendesain ruangan beserta pintu dan jendela sesuai fungsinya; mendesain jalan dari pintu ke pintu atau dari ruangan ke ruangan; menata perabot sesuai peruntukan dalam ruangan. Dari dalam, rumah memiliki schema untuk pengembangan dan fungsi sesuai misinya; dari luar, bangunan rumah merefleksikan fungsi-fungsi ruangan sekaligus mengkomunikasikan visi pemiliknya.

Model ini menjadi menjadi titik temu antara harapan siswa dan harapan pengajar; antara apa yang ingin dipelajari siswa dengan apa yang akan disampaikan pengajar: di bagian mana ilmu baru yang disampaikan pengajar akan direlokasi dalam skema berpikir siswa? Bila tidak compatible dengan model yang dimiliki siswa, atau tidak terdapat slot yang sesuai dengan skema pengembangan alam pikir siswa, maka di sini siswa tidak memperoleh akses untuk belajar ilmu baru.

\section{d. Ketika Tidak Ditemukan Konteks}

Konteks di sini pengertiannya sederhana, yakni, context of use, yaitu, bagaimana menerapkan teori (dan hypernymnya, konsep) ke dalam praktek; dan menerapkan konsep ke dalam aplikasi. Konsep dan teori diperlukan dalam setiap proses pembelajaran karena keduanya berfungsi memberi arah dan memandu tahapan-tahapan pemahaman. Demikian juga, praktek dan aplikasi diperlukan untuk menginternalisasikan teori dan konsep dan menerapkan keduanya dalam kehidupan.

Penerapan teori melalui praktek membuat materi pembelajaran hidup dalam alam pikir individu-masyarakat dan membentuk inter-relasi yang dinamis antara yang simbolis dan abstrak dengan yang faktual dan kongkrit. Teori yang tidak menemukan konteks aplikasi di lapangan akan sulit untuk masuk ke dalam pemahaman siswa sehingga tidak menjadi bagian yang membentuk model perkembangan kognisinya. Bila inkongruensi antara teori (konsep) dan praktek (aplikasi) berlangsung lama dan kronis, materi pelajaran tidak akan membangun fondasi bagi sistem keterampilan dan berpikir siswa, dan "attitude of loving to 
learn and learning to love", malah hanya akan menjadi beban bagi pikirannya. Siswa dengan beban seperti ini akan bertingkah laku seperti zombie: hilang cahaya pikirannya yang cemerlang karena hafalan-hafalan yang teramat banyak, berulang-ulang, tidak bermakna, dan tidak berguna untuk hidup dan bermasyarakat.

Pembelajaran yang efektif terletak pada seni membuat teori yang serba abstrak dan tampak inaccessible menjadi kongkrit dan mudah dipahami serta membangun attitude pada siswa untuk senang berinteraksi dengan maknamakna baru. Kegagalan pemahaman lazimnya dikaitkan dengan rote learning; bukan berarti rote learning tidak penting, namun ia hanya merupakan satu bagian kecil dari proses panjang pembelajaran yang dinamis. Lebih bijak untuk membiarkan siswa sedikit saja hafal materi konten dan sisanya yang lebih banyak adalah ruang untuk mengembangkan kreativitas: bereksperimen dengan makna.

Mari ambil sebuah contoh untuk pembelajaran bahasa (mis. dalam hal ini Bahasa Inggris), yakni, "meaning as a system". Banyak kalangan berpendapat konsep ini terlalu abstrak--hanya bisa diakses oleh siswa/mahasiswa tingkat tinggi. Dalam hal ini izinkan penulis berpendapat berbeda (sedikit Vygotskian, sedikit Chomskian) bahwa semua siswa pada semua tingkatan memahami "meaning as a system." Mereka paham apa itu "meaning"; dan mereka paham apa itu "system". Mereka paham bahwa "meaning" dihasilkan dari sejumlah pengamatan yang konsisten; dan mereka paham bahwa "meaning" dibangun atas susunan tertentu. Yang mereka tidak paham adalah himpunan peristilahan abstrak yang menyertai premis ini. Dan yang kadang membuat mereka tidak paham adalah justru "penjelasan" yang sering lebih rumit dari pada yang dijelaskan.

Dengan caranya yang unik pada tingkat intelegensianya yang serba terbatas sejak kanak-kanak siswa telah belajar berbagai obyek, mengamati dengan tajam kejadian-kejadian, dan meresapi makna-makna. Sejak kanak-kanak mereka telah belajar mencermati simbol-simbol: belajar mengidentifikasi fakta, belajar memilah data, dan belajar membuat generalisasi. Pendidikan bertugas menyediakan model-model berlatih dan bernalar agar kemampuan berjalan lebih strategis, fleksible, efisien.

Suatu teori atau konsep yang tidak bisa ditemukan maknanya dalam kehidupan nyata adalah nonsense; mereka memahami itu. Mereka juga memahami bahwa makna akan berubah ketika susunan premis berubah, atau ketika direct audience 
berubah; ketika kata bersanding dengan gestur dan kinesik tertentu, ketika ada satu atau dua bagian dihilangkan dari premis, ketika ada leksis lain masuk premis, ketika variety dan konteks sosial tidak sama, ketika modalitas yang berbeda digunakan untuk ekspresi yang sama, ketika prosody dan fonologi tidak berterima seperti biasanya, dan sebagainya. Perubahan-perubahan ini terjadi pada level praktis; context of use dibuat secara sistematis untuk memahamkan bagaimana sistem makna bekerja.

\section{e. Ketika Tidak Terdapat "Purpose And Structure"}

Tidak semua tindakan guru (pengajar) di kelas bernilai pedagogis (pedagogical value). Tindakan yang bernilai pedagogis bersifat khas, merupakan cerminan dari skenario yang dirancang sistematis dalam RPP, sesuai konteks lokal dan spesifik, dan menghasilkan respons dalam bentuk proses atau perubahan tingkah-laku siswa.

Salah satu bagian dari tindakan guru yang penting---artinya yang bernilai pedagogis---adalah Penjelasan Guru (sengaja menggunakan huruf besar P dan G untuk menggambarkan momen kategoris dalam proses didaktik). Yang dimaksud penjelasan adalah apa yang disampaikan guru sebagai bagian dari strategi pembelajaran baik untuk mentransmisikan pengetahuan (causality, principle), atau mengkondisikan perubahan perilaku siswa (reasoning, competency). Gaya bahasa dan pembawaan disesuaikan dengan konteks.

Penjelasan guru ini diperlukan karena merupakan amanah tujuan pembelajaran dan konsekuensi logis dari struktur subjek materi. Dengan demikian penjelasan guru bersifat terfokus dan terintegrasi (sesuai topic/theme), terstruktur (memiliki coherence), runut (memperlihatkan order), eksplisit (atas dasar principles/cases), dan sistematis (sesuai dengan method yang digunakan). Sebagaimana sebutannya, Penjelasan Guru bersifat menjelaskan (explain), yang artinya mendudukkan materi dalam konstruksi sebab-akibat. Oleh karena itu Penjelasan Guru memiliki fungsi memberi arah (orienting) dan struktur (structuring) selain fungsi utamanya yakni menyampaikan konten utuh yang memiliki kejelasan scope dan coverage.

Secara garis besar Penjelasan Guru 1) diniatkan untuk merealisasikan tujuan pembelajaran secara keseluruhan; 2) mengelaborasi materi dengan rinci sesuai tema subyek, prinsip dasar, dan kasus-kasus yang relevan; 3) mengaitkan materi dengan urut satu bagian ke bagian lain sehingga membentuk narasi yang baik sebagai kesatuan materi yang utuh; 4) diberikan sesuai dengan kaidah-kaidah 
desain pembelajaran yang digunakan, melibatkan prinsip-prinsip multimodalitas---beyond ceramah yang monodirectional dan context-deficit; dan 5) berdampak langsung pada kemampuan siswa untuk menguasai konsep-konsep sebagai bagian dari proses membangun kompetensi.

Kegagalan siswa memahami konsep-konsep rumit dan abstrak banyak disebabkan oleh ketiadaan Penjelasan Guru. Penjelasan yang baik merupakan pintu masuk untuk menguasai ilmu.

Itulah beberapa dari faktor-faktor yang bisa menjadi penghambat akses untuk merdeka belajar. Guru (pengajar), didukung sekolah, bertugas mengidentifikasi apakah terdapat potensi hambatan; sejak dari penciptaan lingkungan yang kondusif untuk belajar, pemihakan pada siswa, penciptaan model yang sesuai, pemilihan konteks penerapan yang tepat, hingga strategi penjelasan guru.

\section{Keuntungan Adanya Konsep Merdeka Belajar}

\section{a. Pengembangan pola piker}

Konsep pendidikan "merdeka belajar" memiliki fokus pada pengembangan kemampuan kognitif siswa. Artinya, siswa akan ditantang untuk mampu berpikir kritis dengan analisis yang baik. Kemampuan inilah yang dibutuhkan siswa agar bisa membuat keputusan yang bijak dalam penyelesaian masalah. Sebab, dalam industri 4.0 basisnya adalah data technology dengan kata lain informasi yang bisa diakses oleh semua orang. Siswa yang tidak mampu menganalisis semua informasi tersebut tentu akan gagal membuat analisis serta kesimpulan yang benar dan akurat. Hal ini tentu akan menjadi masalah ketika para siswa masuk ke dunia industri yang telah mengadopsi machine learning dan kecerdasan buatan (AI).

\section{b. Inovasi di tingkat Pendidikan}

Salah atu pokok dari konsep pendidikan baru ini adalah membuat siswa mampu mengembangkan minat dan bakatnya di sekolah. Oleh karena itu, pemerintah menghapus penilaian melalui UN, dan menggantinya menjadi penugasan dan portofolio. Alasannya jelas, siswa akan ditantang untuk mampu berinovasi terhadap instrumen dan penyelesaian masalah. Fokusnya adalah bagaimana siswa mampu menjawab persoalan dalam bentuk proyek mata pelajaran dari sekolah. Proses ini penting bagi para siswa untuk belajar mengaplikasikan teori yang mereka pelajari di kelas menjadi sebuah hasil yang nyata. Siswa akan belajar membuktikan, bukan hanya menghafal materi. 


\section{c. Meningkatkan kecerdasan siswa}

Dalam kurikulum pendidikan 4.0, pemerintah telah merancang standar khusus agar siswa Indonesia semakin terlatih kemampuan kognitifnya, dan semakin mampu menyelesaikan masalah dengan baik

\section{Kelemahan Yang Disebabkan Oleh Adanya Konsep Merdeka Belajar}

a. Dengan UN 2021 yang dirubah menjadi Asesment Kompetensi Minimum dan Survei Karakter (Askomi suka) yang diberikan pada siswa ditengah jenjang tingkat (kelas 4,8 dan 11), siswa tidak dapat dilihat pengetahuan yang mendukung kemampuan skillnya karena Askomi suka hanya pada karater dan kepribadiannya saja. Intinya di Askomi suka hanya pada kemampuan Sikap dan sedikit pengetahuannya secara umum. Ini cocok untuk sekolah umum tapi tidak cocok untuk SMK karena tidak dapat dilihat kemampuan skillnya. Disini juga akan menyebabkan siswa malas untuk belajar maupun melaksanakan tindakkan yang ditugaskan oleh guru mata pelajaran. Kemudian dikelas 5,6,9 dan 12. pada tahun 2022 pembelajaran apa yang akan dijalankan.

b. RPP hanya terdiri dari tiga komponen dan hanya satu lembar. RPP adalah rencana pelaksanaan pembelajaran (arah pembelajaran) di kelas yang kita gunakan. Tetapi bila RPP hanya satu lembar tidak bisa dilihat arahnya karena tidak diketahui Indikator, media, peralatan dan bahan yang digunakan dan sumber belajar. Kelemahan lain adalah tidak lengkapnya peralatan dan bahan praktik serta media pembelajaran di sekolah yang mendukung. Sehingga untuk tercapai pembelajaran tidak tercapai sesuai target jam yang ditentukan pemeritah dalam 1 tahun.

c. Bila empat arah kebijakan ini dijalankan tetapi pendidikan harus wajib tuntas pembelajaran siswa (KKM) artinya empat arah kebijakan ini sama saja sistem pendidikan yang sudah berjalan sekarang ini sehingga anak akan manja dan malas belajar karena adanya "Remedial". Dengan demikian untuk memdapatkan sumber Daya Manusia (SDM) yang unggul sesuai keahlianya tidak tercapai.

d. Siswa Kelas 4, 8 dan 11 pada tahun 2019/2020 menjadi Korban akibat penerapan Askomi suka (Asesment Kompetensi Minimum dan Survei Karakter). Siswa ini pada saat penerapan Askomi suka pengganti UN pada tahun pelajaran 2020/2021 atau tahun 2021 sudah naik kelas 5, 9 dan 12. Semoga kemendikbud mempunyai langkah terbaik untuk siswa kelas ini. 


\section{CONCLUSION}

\section{Kesimpulan}

Pembangunan pendidikan merdeka belajar dalam sistem dan pengajarannya harus memenuhi kecenderungan dalam pendidikan di era Revolusi Industri 4.0. Di era Revolusi Industri 4.0 kebutuhan utama yang ingin dicapai dalam sistem pendidikan atau lebih khusus dalam metode pembelajaran yaitu siswa atau peserta didik. Dan sistem atau metode pembelajaran pada pendidikan merdeka belajar mempunyai target yang sama. Jika perserta didik atau siswa dapat mengusaai literasi baru ini, maka akan menjadi sumber daya manusia yang berkualitas dan unggul dalam membangun masa depan Indonesia. Namun selain literasi baru, sistem pendidikan merdeka belajar tetap melakukan pembangunan karakter pada peserta didik, seperti kejujuran, religius, kerja keras/tekun, tanggung jawab, adil, disiplin, toleran, dan lainlain. Tujuannya tentu ingin mencapai tujuan pendidikan yaitu mewujudkan murid atau peserta didik yang berfikir kritis dan memecahkan masalah, kreatif dan berinovasi, terampil berkomunikasi dan berkolaborasi, dan berkarakter. Oleh sebab itu, dalam rencana pelaksanaan kegiatan belajar harus mampu melewati tantangan dan memanfaatkan peluang pendidikan di era Revolusi Industri 4.0. Dan guru menjadi kunci keberhasilan sistem pendidikan merdeka belajar, oleh sebab itu harus dapat beradaptasi dengan sistem pendidikan yang baru agar memiliki kopetensi dan keterampilan. Penguatan literasi baru pada guru sebagai kunci perubahan, termasuk revitalisasi kurikulum berbasis literasi dan penguatan peran guru yang memiliki kompetensi digital. Maka metode Blended Learning sangat ideal sebagai metode pembelajaran di sistem pendidikan merdeka belajar. Metode pembelajarannya yaitu menggabungkan keunggulan pembelajaran yang dilakukan secara tatap-muka dan secara virtual.

\section{Saran}

Penulis mendapatkan pengalaman yang sangat berharga dalam mengobservasi serta meneliti makalah ini, saran dari penulis untuk kepada semua pembaca untuk terus bersama-sama untuk membuat pendidikan kita khususnya di negara ini semakin baik, dengan adanya konsep merdeka dalam belajar semoga membuat kita semua tersadar bahwa masa depan bangsa ini ada di para pemuda yang berpendidikan. Dengan kata lain kita semua ikut bertanggung jawab untuk meningkatkan kualitas pendidikan, serta memperbarui sistem yang di rasa sudah tertinggal. Karena dengan meminimalisir semua kekurangan dan juga dampak buruk dari sistem yang sudah tertera membuat perkembangan pendidikan serta pembelajaran negara kita semakin 
baik dan tidak ada salahnya juga untuk mencontoh sistem dari negara lain jika memang bisa di terapkan di negara Indonesia. Dan sebagai anak muda penulis berharap bahwa perubahan serta konsep untuk membuat negara ini semakin baik dalam penerapan pembelajaran segera terwujud agar menjadikan negara kita menjadi bangsa yang kuat juga bangsa yang cerdas. Penulis juga memiliki saran untuk sistem pendidikan yang bisa di terapkan, yaitu dengan sistem "Minat Bakat" dengan menerapkan sistem ini dirasa akan membantu para siswa yang sedang belajar untuk meningkatkan potensi dalam diri mereka masing-masing. Dengan kata lain para siswa dengan mudah tahu mereka kuat dalam bidang apa dan mampu dalam menyelesaikan masalah yang mereka sendiri paham caranya. Sistem ini pun sudah banyak di terapkan di negara-negara besar seperti Eropa dan negara Amerika serikat. Dan terbukti bahwa sistem pendidikan "Minat Bakat" membuat negara-negara besar tersebut memiliki potensi yang baik di masa sekarang karena mereka mampu membuat para siswanya berperan dalam menutupi serta membuat era baru dalam belajar, saya harap (penulis) di kemudian hari para pemimpin negara ini mampu mengkaji ulang serta mengganti sistem yang berjalan sekarang karena menurut saya (penulis) sistem ini sudah di anggap kuno. Karena persoalan Merdeka Dalam Belajar ini adalah Tanggung jawab semua anak Bangsa.

\section{REFERENCCES}

Ali, M. (2009). Pendidikan untuk pembangunan nasional: Menuju bangsa Indonesia yang mandiri dan berdaya saing tinggi. Grasindo.

Arifin, S., \& Muslim, M. O. H. (2020). Tantangan Implementasi Kebijakan "Merdeka Belajar, Kampus Merdeka" pada Perguruan Tinggi Islam Swasta di Indonesia. Jurnal Pendidikan Islam Al-Ilmi, 3(1).

Chrismastianto, I. A. W. (2021). MERDEKA: TUJUH LANGKAH TAKTIS PERGURUAN TINGGI MERESPONS KEBIJAKAN KAMPUS MERDEKA DALAM KONTEKS NEW NORMAL (Book Series Kampus Merdeka Seri II).

Farikhah, S. (2015). Manajemen lembaga pendidikan. Aswaja Presindo.

Gunawan, I. (2013). Metode penelitian kualitatif. Jakarta: Bumi Aksara, 143. 
Hakim, L. (2016). Pemerataan akses pendidikan bagi rakyat sesuai dengan amanat Undang-Undang Nomor 20 Tahun 2003 tentang Sistem Pendidikan Nasional. EduTech: Jurnal Ilmu Pendidikan Dan Ilmu Sosial, 2(1).

Hayati, N. (2018). FORMULASI PENDIDIKAN ISLAM DALAM QS ALI IMRAN AYAT 110. Aqidah-Ta: Jurnal Ilmu Aqidah, 3(2).

Herkusumo, A. P. (2011). Penyetaraan (equating) ujian akhir sekolah berstandar nasional (UASBN) dengan teori tes klasik. Jurnal Pendidikan Dan Kebudayaan, $17(4), 455-471$.

Junaid, H. (2016). Sumber, Azas Dan Landasan Pendidikan (Kajian Fungsionalisasi secara makro dan mikro terhadap rumusan kebijakan pendidikan nasional). Sulesana: Jurnal Wawasan Keislaman, 7(2), 84-102.

Lestari, H. A., \& Rosdiana, W. (2018). Implementasi Kebijakan Penerimaan Peserta Didik Baru (PPDB) di SMA Negeri 4 Kota Madiun Tahun 2017. Publika, 6(5).

Maisaroh, E. N., \& Falah, F. (2021). Religiusitas dan kecemasan menghadapi ujian nasional (UN) pada siswa madrasah aliyah. Proyeksi: Jurnal Psikologi, 6(2), 7888.

Mardapi, D., \& Kartowagiran, B. (2009). Dampak ujian nasional. Laporan Hasil Penelitian Jurusan PEP.

Muhsin, H. (2021). Kampus Merdeka Di Era New Normal. Masa Depan Kampus Merdeka \& Merdeka Belajar: Sebuah Bunga Rampai Dosen, 143.

Mustaghfiroh, S. (2020). Konsep "merdeka belajar" perspektif aliran progresivisme John Dewey. Jurnal Studi Guru Dan Pembelajaran, 3(1), 141-147.

Nata, H. A. (2016). Pendidikan dalam perspektif Al-Qur'an. Prenada Media. 
Prastowo, A. (2017). Menyusun Rencana Pelaksanaan Pembelajaran (RPP) Tematik Terpadu: Implementasi Kurikulum 2018 untuk SD/MI. Kencana.

Purwanti, D. (2019). Efektivitas kebijakan penerimaan peserta didik baru sistem zonasi bagi siswa rawan melanjutkan pendidikan (The Effectiveness of New Student Admission of Zoning System Policy for Students Prone to Continue Education). Dinamika: Jurnal Ilmiah Ilmu Administrasi Negara, 5(4), 1-7.

Purwanti, D., Irawati, I., Adiwisastra, J., \& Bekti, H. (2019). Implementasi Kebijakan Penerimaan Peserta Didik Baru Berdasarkan Sistem Zonasi Di Kota Bandung. Jurnal Governansi, 5(1), 12-23.

Rohidayati, R. (2015). Nilai-nilai pendidikan profetik dalam QS. Ali Imran 110 [PhD Thesis]. UIN Walisongo.

Sherly, S., Dharma, E., \& Sihombing, H. B. (2020). Merdeka belajar: Kajian literatur. UrbanGreen Conference Proceeding Library, 1, 183-190.

Sirait, S. C. (2017). Tanggung Jawab Pemerintah untuk Memberikan Pendidikan kepada Anak Terlantar dalam Perspektif Undang-Undang Perlindungan Anak. DE LEGA LATA: Jurnal Ilmu Hukum, 2(1), 158-182.

Sulaiman, M., Al Hamdani, M. D., \& Aziz, A. (2018). Emotional Spiritual Quotient (Esq) Dalam Pembelajaran Pendidikan Agama Islam Kurikulum 2013. Jurnal Penelitian Pendidikan Islam,[SL], 6(1), 77-110.

Suprayitno, A., \& Wahyudi, W. (2020). Pendidikan Karakter di Era Milenial. Deepublish. Suwandi, S. (2013). Evaluasi Pelaksanaan Ujian Akhir Sekolah Berstandar Nasional (Uasbn). Jurnal Pendidikan Teknologi Dan Kejuruan, 21(3).

Tohir, M. (2020). Merdeka Belajar: Kampus Merdeka.

Wijayanto, A. (2021). Implementasi dan Problematika Merdeka Belajar. 
Wikanengsih, W., Nofiyanti, N., Ismayani, M., \& Permana, I. (2015). Analisis Rencana Pelaksanaan Pembelajaran (RPP) Mata Pelajaran Bahasa Indonesia (Studi terhadap RPP yang Disusun Guru Bahasa Indonesia Tingkat SMP di Kota Cimahi). Jurnal Ilmiah P2M STKIP Siliwangi, 2(1), 106-119. 